Nig. J. Anim. Prod. 2017 44(2):262 - 270

(C) Nigerian Society for Animal Production

Nigerian Journal of Animal Production

\title{
Effect of African nutmeg (Monodora myristica) spice in aflatoxin-infected diets on growth performance of broilers
}

${ }^{1}$ Onunkwo, D. N. and ${ }^{1}$ Ukoha, O. A.

${ }^{1}$ Department of Animal Nutrition and Forage Science, College of Animal Science and Animal Production, Michael Okpara University of Agriculture, Umudike,

Umuahia, Abia State, Nigeria.

*Corresponding author's email: donunkwo1@gmail.com;

Abstract $+2348033388622$

Fungal infected feedstuffs are denatured in nutrients and cause them to develop off flavors that often dampen the appetite of livestock and poultry. In this study, the effect of toasted African nutmeg (Monodora myristica) spice in Aspergillus flavus-infested diets on growth performance of broilers was investigated in a $2 \times 3$ factorial experimentthat lasted for 42 days. Three out of 6 dietary treatments were infected with $1 \mathrm{mg}$ of pure culture of Aspergillus flavus and toasted Monodora myristica spice included at $0 \%, 0.5 \%$ and $1.0 \%$ while the other 3 diets were infection-free with $0 \%, 0.5 \%$ and $1.0 \%$ Monodora myristica inclusion respectively. Each treatment was replicated three times at 30 chickens per replicate. Infection status was significant $(P<0.05)$ for daily weight gain, feed conversion ratio $(F C R)$ and protein efficiency ratio (PER). Daily weight gain, feed conversion ratio and protein efficiency ratio were $134.19 \mathrm{~g} / \mathrm{bird} /$ day, 39.23g/bird/day, 3.59g/bird/day and $1.10 \mathrm{~g} / \mathrm{bird} /$ day, respectively for the non-infected diets. The aflatoxin infection from Aspergillus flavus was observed to reduce $(P<0.05)$ feed intake to $130.51 \mathrm{~g} / \mathrm{bird} /$ day and weight gain $(33.67 \mathrm{~g} / \mathrm{bird} /$ day). FCR and PER were also reduced $(P<0.05)$ by the presence of aflatoxin from Aspergillus flavus in the diet. Effect of Monodora myristica supplementation on feed intake, average daily weight gain, $F C R$ and Protein efficiency ratio was significant $(P<0.05)$ for all the measured parameters. The Feed intake, average daily weight gain, FCR and protein efficiency increased $(P<0.05)$ as Monodora myristica inclusion level increased. Feed intake $(119.8 \mathrm{~g} / \mathrm{b} / \mathrm{d})$, daily weight gain $(28.90 \mathrm{~g} / \mathrm{b} / \mathrm{d}), F C R$ (4.28) and PER (0.94) were observed in the Monodora-free $(0 \%)$ diet. $0.5 \%$ and $1.0 \%$ levels of Monodora inclusion produced similar $(P>0.05)$ effects on all the growth parameters but were higher than the control. The interaction of aflatoxin infection and Monodora inclusion level were significant for all the growth parameters. The interaction of aflatoxin infection x Monodora inclusion levels recorded feed intake of $107.97 \mathrm{~g} / \mathrm{b} / \mathrm{d}, 137.36$ and $146.19 \mathrm{~g} / \mathrm{b} / \mathrm{d}$ respectively for $0,0.5$ and $1.0 \%$ Monodora; $22.27 \mathrm{~g} / \mathrm{b} / \mathrm{d}, 37.87 \mathrm{~g} / \mathrm{b} / \mathrm{d}$ and $40.83 \mathrm{~g} / \mathrm{b} / \mathrm{d}$ daily weight gain and $4.85 \%, 3.63 \%$ and $3.58 \%$ FCR. The interaction effect of Monodora inclusion level in infection-free diets on the birds feed intake were $131.65 \mathrm{~g} / \mathrm{b} / \mathrm{d}$, $147.24 \mathrm{~g} / \mathrm{b} / \mathrm{d}$ and $123.67 \mathrm{~g} / \mathrm{b} / \mathrm{d}$ respectively for $0 \%, 0.5 \%$ and $1.0 \%$. The interaction effect at $0.5 \%$ inclusion level $x$ non-infected diet was significantly higher $(41.31 \mathrm{~g} / \mathrm{b} / \mathrm{d})$ than that at $0 \%$ inclusion level on daily gain. However, the daily weight gain of $40.83 \mathrm{~g} / \mathrm{b} / \mathrm{d}$ observed in the interaction of $1.0 \%$ Monodora level $x$ aflatoxin-free diet similar $(P<0.05)$ to that observed in the $0.5 \%$ inclusion level. The feed conversion ratio produced by the interactions at the three different levels (0, 0.5 and 1.0\%) in the Aspergillus-free diets were $(P>0.05) 3.71,3.57$ and 3.49 respectively while PER were $(P<0.05) 1.05,1.13$ and 1.11 respectively. The Monodorafree diet recorded $9.26 \%$ drumstick, $2.26 \%$ liver $0.65 \%$ kidney and $2.43 \%$ gizzard, while the diet that had $0.5 \%$ Monodora myristica yielded $2.12 \%$ liver and $2.29 \%$ gizzard. Inclusion of Monodora up to $1.0 \%$ recorded $1.63 \%$ liver weight. Aspergillus flavus alone caused a reduction in live weight, dressed weight, thigh, kidney, breast meat, gizzard and an 


\section{Effect of African nutmeg (Monodora myristica)spicein aflatoxin-infected diets on growth performance of broilers}

enlargement in the liver. Monodora myristica inclusion level also affected $(p<0.05)$ all the parameters except dressed weight, thigh and back cut. Kidney and liver were observed to decrease as the level of inclusion of Monodora myristica increased. The interaction of Monodora myristica and Aspergillus flavus on the parameters were significant $(p<0.05)$. From the results, Monodora myristica may be beneficial to poultry farmers, since about $90 \%$ of the poultry feed ingredients especially grains are constantly exposed to aflatoxin infection from Aspergillus flavus and other mycotoxin infections which hinder maximum nutrient utilization and affect the rate of conversion offeed.

Keywords: Aflatoxin, Monodora Myristica, Aspergillus flavus. growth performance, broiler birds

\section{Introduction}

Farmers in Nigeria are faced with an increasing challenge of poor storage facilities. Most often the feedstuffs under these poor storage conditions become mouldy. The moulds which are fungal in nature denature the nutrients of the feed and cause them to develop off flavour that dampen the appetite of the animals which are fed these feeds. Also, their presence in feed ingredients leads to the introduction of mycotoxin known as Aflatoxin. Aflatoxins, the most dangerous mycotoxins, are toxigenic secondary metabolites of fungi produced by certain strains of Aspergillus species - A.flavus, A. parasiticus and A. nomis (Fente et al., 2001). These fungi can produce their toxic compounds on almost any food that will support growth. They often grow on agricultural products especially on grains such as groundnuts and maize. The metabolites produced by these fungi include $\mathrm{AFB}_{1}, \mathrm{AFB}_{2}, \mathrm{AFG}_{1}$ and $\mathrm{AFG}_{2}$, all of which occur naturally (Kozakiewic and Smith, 1994). $\mathrm{AFB}_{1}$ and $\mathrm{AFB}_{2}$ are produced by Aspergillus flavus while $A$. parasiticus produces these same metabolites along with $\mathrm{AFG}_{1}$ and $\mathrm{AFG}_{2}$. Of the four metabolites, $\mathrm{AFB}_{1}$ is found in highest concentrations followed by $\mathrm{AFG}_{1}$. Due to their ability to grow on almost all food products, they can generate off flavours, produce toxins, and cause discolouration and proteolysis (Alharthi,
1997). Aflatoxin has been reported to have adverse effects on poultry. McDonald et al. (1995) reported high level of turkey poults and duckling poisoning as a result of groundnut infestation with Aspergillus flavus. The principal target organ of Aflatoxin is the liver (Alharthi, 1997). Animals which consume sub-lethal quantities of aflatoxin for several days or weeks develop a sub-acute toxicity syndrome which commonly includes moderate to severe liver damage with marked bile duct proliferation. Sonia et al. (1997) reported that even with low levels of aflatoxin in the animal feed, there would be a decrease in growth rate, lowered milk and egg production and suppression of immunity. Carcinogenicity has been attributed to aflatoxin $\mathrm{B}_{1}$. Alharti (1997) reported that in chronic toxicity, liver becomes damaged and gall bladder becomes swollen. After the invasion of aflatoxin into the liver, lipids infiltrate the hepatocytes and lead to necrosis or liver cell death. He reported that the $\mathrm{LD}_{50}$ of a day-old duckling is $0.3 \mathrm{mg} / \mathrm{kg}$ body weight. The effect of aflatoxicosis can be compounded by stress and this can lead to induced haemorrhaging due to prolonged blood clotting time caused by lack of vitamin $\mathrm{K}$ utilization. The study was conducted to evaluate the effect of Monodora myristica on the growth performance parameters of birds fed diets infested with Aspergillus 


\section{Onunkwo and Ukoha}

flavus.

\section{Materials and methods}

Seeds of Monodora myristica were bought from Ndoro Market in Ikwuano Local Government Area of Abia State. They were cleaned and toasted at $65^{\circ} \mathrm{C}$ for one hour. Then they were milled into powder, bottled in an airtight container and then analyzed for its proximate composition according to the procedure of the A.O.A.C (1990). The Vitamin (ascorbic acid, thiamine, riboflavin and niacin) and Mineral compositions were also analyzed using the Johnson and Ulrich (1959) method and Barakat et al., (1973) respectively as outlined by Okwu (2004).

The experiment lasted for forty-two days. The broiler birds were stabilized for fourteen days on standard broiler starter diet and thereafter randomly allocated to six treatment diets in a $2 \times 3$ factorial in Completely Randomized Design experiment. Factor A was aflatoxin infection status at two levels (infection and non-infection) and factor $\mathrm{B}$ was inclusion level at three levels $(0 \%, 0.5 \%$ and $1.0 \%)$ of Monodora spice. A total of 540 unsexed Anak broiler birds were randomly allocated to six diets and replicated three times with thirty birds per replicate. The first three diets designated 1,2 and 3 respectively were diets each infected with $1 \mathrm{~mL}$ pure culture of Aspergillus flavus obtained from the Plant Pathology Laboratory of the National Root Crop Research Institute, Umudike in Abia State of Nigeria and supplemented with $0 \%$ (infected control), $0.5 \%$ and $1.0 \%$ milled Monodora myristica. The remaining three diets 4, 5 and 6 were not infected with Aspergillus flavus, but were also supplemented with $0 \%$ (noninfected control), $0.5 \%$ and $1.0 \% M$. myristica spice. The broiler chicks were raised on deep litter floor. Routine management and vaccination procedures were followed. The diets in mash form and water were provided ad-libitum. Records of feed consumption and liveweight were taken weekly on a group basis throughout the 49days duration of the experiment.

\section{Statistical analysis}

The data collected were subjected to Analysis of Variance (ANOVA) in a 2x3 factorial arrangement in a completely randomized design experiment and where significant differences were obtained, means were separated using Duncan's Multiple Range Test (Duncan, 1955) as packaged in SPSS (2006) for windows; version 16, SPSS Inc.

\section{Results}

The results of the average weight gain, feed intake and feed conversion ratio of broilers fed Aspergillus flavus-infected or noninfected diets with or without Monodora myristica additives are shown in Table 2.

Infection status effect was significant $(\mathrm{P}<0.05)$ for daily weight, feed conversion ratio and protein efficiency ratio. Daily weight gain, feed conversion ratio and protein efficiency ratio were $39.23 \mathrm{~g} / \mathrm{b} / \mathrm{d}$, 3.59 and 1.10 respectively for the noninfected diets while, the infected diets were lower $(\mathrm{P}<0.05)$ for daily gain $(33.67 \mathrm{~g} / \mathrm{b} / \mathrm{d})$, FCR (4.02) and PER (1.05). There was no significant $(\mathrm{P}>0.05)$ infection status main effect on feed intake. Average feed intake was $130.51 \mathrm{~g} / \mathrm{b} / \mathrm{d}$ and $134.19 \mathrm{~g} / \mathrm{b} / \mathrm{d}$ for infected and non-infected diets, respectively.

Monodora myristica inclusion level significantly $(\mathrm{P}<0.05)$ affected all the growth parameters. Lowest $(\mathrm{P}<0.05)$ feed intake of $119.81 \mathrm{~g} / \mathrm{b} / \mathrm{d}$, daily weight gain $(28.90 \mathrm{~g} / \mathrm{b} / \mathrm{d})$, feed conversion ratio $(4.28)$ and PER (0.94) were observed in the Monodora-free (0\%) diet. However, 0.5\% recorded $142.24 \mathrm{~g} / \mathrm{b} / \mathrm{d}$ feed intake, $39.59 \mathrm{~g} / \mathrm{b} / \mathrm{d}$ daily weight gain, $3.60 \mathrm{FCR}$ and 1.13 PER while $1.0 \%$ Monodora inclusion 
Effect of African nutmeg (Monodora myristica)spicein aflatoxin-infected diets on growth performance of broilers

Table 1: Dietary composition of Aspergillus -infested and non -infested broiler diets supplemented with and without Monodora myristica

\begin{tabular}{|c|c|c|c|c|c|c|}
\hline \multirow{2}{*}{$\begin{array}{l}\text { INFECTED DIETS } \\
\text { Monodora level }\end{array}$} & \multirow[b]{2}{*}{$0.0 \%$} & \multirow[b]{2}{*}{$0.5 \%$} & \multirow[b]{2}{*}{$1.0 \%$} & \multicolumn{3}{|c|}{ NON-INFECTED DIETS } \\
\hline & & & & $0.0 \%$ & $0.5 \%$ & $1.0 \%$ \\
\hline Maize & 53.00 & 53.00 & 53.00 & 53.00 & 53.00 & 53.00 \\
\hline Soybean & 20.00 & 20.00 & 20.00 & 20.00 & 20.00 & 20.00 \\
\hline Fishmeal & 2.00 & 2.00 & 2.00 & 2.00 & 2.00 & 2.00 \\
\hline G.N.C & 12.00 & 11.50 & 11.00 & 12.00 & 11.50 & 11.00 \\
\hline P.K.C & 3.00 & 3.00 & 3.00 & 3.00 & 3.00 & 3.00 \\
\hline Wheat offal & 4.25 & 4.25 & 4.25 & 4.25 & 4.25 & 4.25 \\
\hline Monodora & 0.00 & 0.50 & 1.00 & 0.00 & 0.50 & 1.00 \\
\hline Bone meal & 3.00 & 3.00 & 3.00 & 3.00 & 3.00 & 3.00 \\
\hline Oyster & 2.00 & 2.00 & 2.00 & 2.00 & 2.00 & 2.00 \\
\hline Methionine & 0.10 & 0.10 & 0.10 & 0.10 & 0.10 & 0.10 \\
\hline Lysine & 0.10 & 0.10 & 0.10 & 0.10 & 0.10 & 0.10 \\
\hline Salt & 0.30 & 0.30 & 0.30 & 0.30 & 0.30 & 0.30 \\
\hline Vit/min premix & 0.25 & 0.25 & 0.25 & 0.25 & 0.25 & 0.25 \\
\hline Total & 100 & 100 & 100 & 100 & 100 & 100 \\
\hline Calc.ME(kcal/kg) & 2912.35 & 2901.37 & 2890.40 & 2912.35 & 2901.37 & 2890.40 \\
\hline CrudeProtein $(\%)$ & 21.68 & 21.58 & 21.49 & 21.68 & 21.58 & 21.49 \\
\hline Calcium (\%) & 1.89 & 1.91 & 1.94 & 1.89 & 1.91 & 1.94 \\
\hline Phosphorus (\%) & 0.94 & 1.13 & 0.43 & 0.94 & 1.13 & 0.43 \\
\hline Lysine (\%) & 1.13 & 1.12 & 1.12 & 1.13 & 1.12 & 1.12 \\
\hline Methionine $(\%)$ & 0.43 & 0.42 & 0.42 & 0.43 & 0.42 & 0.42 \\
\hline Crude fibre (\%) & 3.37 & 3.71 & 3.71 & 3.37 & 3.71 & 3.71 \\
\hline
\end{tabular}

\section{Results}

Table 2 : Effect of Monodora myristica Level of inclusion and Aspergillus flavus on Growth performance of Broilers chickens

\begin{tabular}{|c|c|c|c|c|c|}
\hline Inf. Status & Level of Inc. (\%) & $\begin{array}{l}\text { Feed intake } \\
(\mathrm{g})\end{array}$ & $\begin{array}{l}\text { Daily weight gain } \\
\text { (g/b/d) }\end{array}$ & $\begin{array}{l}\text { FCR } \\
\text { (g feed/g gain) }\end{array}$ & PER \\
\hline Inf. & 0 & $107.97^{\mathrm{c}}$ & $22.27^{\mathrm{c}}$ & $4.85^{\mathrm{c}}$ & $0.84^{\mathrm{c}}$ \\
\hline N.Inf & 0 & $131.65^{\mathrm{b}}$ & $35.54^{\mathrm{b}}$ & $3.71^{\mathrm{b}}$ & $1.05^{\mathrm{b}}$ \\
\hline Inf. & 0.5 & $137.36^{\mathrm{ab}}$ & $37.87^{\mathrm{b}}$ & $3.63^{b}$ & $1.12^{\mathrm{a}}$ \\
\hline N.Inf & 0.5 & $147.24^{\mathrm{a}}$ & $41.31^{\mathrm{a}}$ & $3.57^{\mathrm{b}}$ & $1.13^{\mathrm{a}}$ \\
\hline Inf. & 1.0 & $146 . .19^{a}$ & $40.88^{\mathrm{a}}$ & $3.58^{b}$ & $1.18^{\mathrm{a}}$ \\
\hline \multirow[t]{2}{*}{ N.Inf } & 1.0 & $123.67^{\mathrm{c}}$ & $40.83^{\mathrm{a}}$ & $3.49^{\mathrm{b}}$ & $1.11^{\mathrm{ab}}$ \\
\hline & SEM & 6.31 & 0.80 & 0.08 & 0.02 \\
\hline Infection & Status & & & & \\
\hline Infected & & 130.51 & $33.67^{\mathrm{b}}$ & $4.02^{\mathrm{a}}$ & $1.05^{\mathrm{b}}$ \\
\hline \multirow[t]{2}{*}{ Non-infected } & & 134.19 & $39.23^{\mathrm{a}}$ & $3.59^{\mathrm{b}}$ & $1.10^{\mathrm{a}}$ \\
\hline & SEM & 3.64 & 0.46 & 0.04 & 0.01 \\
\hline \multicolumn{6}{|c|}{ Monodora level main effect } \\
\hline & $0 \%$ & $119.81^{\mathrm{b}}$ & $28.90^{\mathrm{b}}$ & $4.28^{\mathrm{a}}$ & $0.94^{\mathrm{b}}$ \\
\hline & $0.5 \%$ & $142.24^{\mathrm{a}}$ & $39.59^{\mathrm{a}}$ & $3.60^{\mathrm{b}}$ & $1.13^{\mathrm{a}}$ \\
\hline & $1.0 \%$ & $144.43^{\mathrm{a}}$ & $40.85^{\mathrm{a}}$ & $3.54^{\mathrm{b}}$ & $1.14^{\mathrm{a}}$ \\
\hline & SEM & 4.458 & 0.564 & 0.054 & 0.016 \\
\hline
\end{tabular}

abc- means in the same column with the same superscript are not significantly $(\mathrm{P}>0.05)$ different from one another.

Inf. and Non-infected represent infected and non-infected respectively. 


\section{Onunkwo and Ukoha}

levels yielded a daily feed intake of $144.43 \mathrm{~g} / \mathrm{b} / \mathrm{d}$, daily weight gain (40.85g/b/d), FCR (3.54) and PER (1.14).

The interactions effect of aflatoxin infection from Aspergillus flavus x Monodora inclusion level were significant $(\mathrm{P}<0.05)$ for all the parameters. The infected control diet had $0 \%$ Monodoraand was the least $(\mathrm{P}<0.05)$ consumed $(107.97 \mathrm{~g} / \mathrm{b} / \mathrm{d})$, and also recorded the least daily weight gain $(22.27 \mathrm{~g} / \mathrm{b} / \mathrm{d})$, feed conversion ratio $(4.85)$ and PER (0.84). Average feed intake of the infected diet increased $(\mathrm{P}<0.05)$ above the control to $137.36 \mathrm{~g} / \mathrm{b} / \mathrm{d}$ and $146.19 \mathrm{~g} / \mathrm{b} / \mathrm{d}$ respectively as Monodora was included at $0.5 \%$ and increased to $1.0 \%$. The inclusion of Monodora in the infected diet at 1.0\% level yielded feed conversion ratio and protein efficiency ratio of 3.58 and 1.18 respectively. Similar $(\mathrm{P}>0.05)$ effect was recorded with those fed infected diets with $0.5 \%$ Monodora level which recorded FCR (3.63) and PER (1.12). For the non-infected diets, the $1.0 \%$ Monodora was least $(\mathrm{P}<0.05)$ consumed $(123.67 \mathrm{~g} / \mathrm{b} / \mathrm{d})$. However, it recorded $40.83 \mathrm{~g} / \mathrm{b} / \mathrm{d}$ weight gain, 3.49 FCR and 1.11 PER. When Monodora was added to aflatoxin-free diet at $0.5 \%$ level, it recorded the highest $(\mathrm{P}<0.05)$ feed intake $(147.24 \mathrm{~g} / \mathrm{b} / \mathrm{d})$, with daily weight gain, FCR and PER of 41.31, 3.57 and 1.13 , respectively. The aflatoxinfree diet with no Monodora supplementation recorded feed intake of $131.65 \mathrm{~g} / \mathrm{b} / \mathrm{d}, 35.54 \mathrm{~g} / \mathrm{b} / \mathrm{d}$ weight gain 3.71 FCR

\section{Discussion}

Average daily feed intake was observed to be depressed by Aspergillus flavus infection. Feed intake was positively affected by Monodora inclusion over the control. The average daily feed intake in the infected feed increased as the levels of Monodora supplementation increased. For the non-infected diets, feed intake also increased as the Monodora level rose to $0.5 \%$ but further increase in the Monodora level beyond that, resulted in the decrease in feed consumption. The reduced feed intake recorded for the infected diet without Monodora could be attributed to the nonpalatability of the diet due to off-flavour that may have been caused by the presence of lipase enzymes in Aspergillus flavus. These enzymes break down the lipid contents of the diets in the process of lipolysis leading to the release of taste that the birds found unacceptable (McDonald et al., 1995). The observed increase in feed intake resulting from the Monodora supplementation was in agreement with the observation made for sanguinaria rhizome on piglets and poultry (Gerbert et al., 1999) and turmeric on laying hens (Samarasinghe and Wenk, 2002). The low feed intake $(123.67 \mathrm{~g} / \mathrm{b} / \mathrm{d})$ by $1.0 \%$ Monodora in the diet that was not infected suggests probably that the flavour from the spicemay have been too high thereby increasing the taste and characteristic pungent odour from the essential oil components. This may not have been tolerated by the birds and thus negatively affected feed intake.From the results, the average feed intake of the non-infected diets at $0 \%, 0.5 \%$ and $1.0 \%$ Monodora level appear to be higher than that obtained from the Mucuna bean-based broiler diet (Ukoha et al, 2011). The lower feed intake of $82.73 \mathrm{~g} / \mathrm{b} / \mathrm{d}, 84.95 \mathrm{~g} / \mathrm{b} / \mathrm{d}$ and $89.67 \mathrm{~g} / \mathrm{b} / \mathrm{d}$ by birds fed Mucuna-based diet with Monodora supplementation at $0 \%, 0.5 \%$ and $1.0 \%$ respectively could probably be as a result of the antinutritional components in the Mucuna cochinchinensis. The difference observed in the feed intake may be an indication that the birds have well developed taste buds as opposed to by the report of Holdas and May (1966).

Inclusion of Monodora myristica in 
Aspergillus flavus diet improved average daily weight gain of birds over the controlfed birds. The least weight gain $(22.27 \mathrm{~g} / \mathrm{b} / \mathrm{d})$ and protein efficiency ratio $(0.84)$ was observed in the Monodora-free infected diet. The weight gain realized by supplementing $0.5 \%$ and $1.0 \%$ Monodora to non-infected diets were not superior to that obtained in the infected diet having $1.0 \%$ Monodora supplementation. The feed conversion ratio in all the groups except the groups fed infected control were similar $(\mathrm{P}<0.05)$. Monodora supplementation improved the protein efficiency ratio in birds fed the infected diets. The low weight and poor utilization of the nutrients in the infected diets with $0 \%$ Monodora could be as a result of the aflatoxin produced by the Aspergillus flavus which may have bound them, making them unavailable for absorption. The poor protein efficiency ratio confirmed this assertion. Monodora at $0.5 \%$ and $1.0 \%$ levels of inclusion were able to neutralize the effect of the aflatoxin and enhance the utilization of the nutrients comparable to the non-infected diets. Monodora was also observed to improve the utilization of non-infected diets especially at levels not exceeding $0.5 \%$.

The observations above were in line with the findings of Alharthi (2006) who reported that aflatoxin at $0.25 \mathrm{ppm}$ in turkey poults and ducklings impaired growth and a dose of $1.5 \mathrm{ppm}$ in broilers and $4.0 \mathrm{ppm}$ in Japanese quail had negative effect on growth. Aspergillus flavus alone appears to impair the availability of bile salts which decrease vitamin D3 production, probably through increased levels of biliary acids in the gastric juice. This also leads to the decrease in the absorption of fat soluble vitamins. Moreover, aflatoxin is known to react negatively with different cell proteins and this leads to the inhibition of carbohydrate and lipid metabolism, protein synthesis and mitochondrial respiration (Sonia et al, 1997).

From the results, Monodora myristica tends to be beneficial to poultry farmers, since about $90 \%$ of the poultry feed ingredients especially grains are constantly exposed to aflatoxin infection from Aspergillus flavus and other mycotoxin infections which hinder maximum nutrient utilization and affect the rate of conversion of feed. Monodora may find a place in future as

Table 3: Effect of Monodoramyristica and Aspergillusflavus infection in broiler diet on organs and cut part weights

\begin{tabular}{|c|c|c|c|c|c|c|c|c|c|c|c|c|c|}
\hline $\begin{array}{l}\text { Inf. } \\
\text { Status }\end{array}$ & $\begin{array}{l}\text { Monodora } \\
\text { Level (\%) }\end{array}$ & $\begin{array}{l}\text { L.W. } \\
(\%)\end{array}$ & $\begin{array}{l}\text { DRW } \\
(\%)\end{array}$ & $\begin{array}{l}\text { DS } \\
(\%)\end{array}$ & \multicolumn{2}{|c|}{$\begin{array}{l}\text { TH } \\
(\%)\end{array}$} & $\begin{array}{l}\text { BM } \\
(\%)\end{array}$ & $\begin{array}{l}\text { Liver } \\
(\%)\end{array}$ & $\begin{array}{l}\text { Gizzard } \\
(\%)\end{array}$ & \multicolumn{3}{|c|}{$\begin{array}{l}\text { Back cut } \\
(\%)\end{array}$} & $\begin{array}{l}\text { Kidney } \\
(\%)\end{array}$ \\
\hline Inf. & 0 & $1310.15^{\mathrm{c}}$ & $85.67^{b}$ & $9.71^{\mathrm{c}}$ & \multicolumn{2}{|c|}{$9.92^{\mathrm{a}}$} & $18.15^{\mathrm{a}}$ & $2.46^{\mathrm{a}}$ & $2.35^{\mathrm{b}}$ & \multicolumn{3}{|c|}{$14.31^{\mathrm{ab}}$} & $0.62^{\mathrm{c}}$ \\
\hline N. Inf & 0 & $1866.67^{b}$ & $94.33^{\mathrm{a}}$ & $8.81^{\mathrm{d}}$ & \multicolumn{2}{|c|}{$9.07^{\mathrm{b}}$} & $15.02^{\mathrm{bcd}}$ & $2.06^{\mathrm{c}}$ & $2.51^{\mathrm{a}}$ & \multicolumn{3}{|c|}{$14.81^{\mathrm{a}}$} & $0.69^{\mathrm{a}}$ \\
\hline Inf. & 0.5 & $1966.67^{b}$ & $92.31^{\mathrm{a}}$ & $9.92^{\mathrm{bc}}$ & \multicolumn{2}{|c|}{$9.39^{\mathrm{ab}}$} & $14.70^{\mathrm{bc}}$ & $2.21^{\mathrm{c}}$ & $2.07^{\mathrm{c}}$ & \multicolumn{3}{|c|}{$14.32^{\mathrm{ab}}$} & $0.59^{c}$ \\
\hline N. Inf. & 0.5 & $2104.63^{a}$ & $91.87^{\mathrm{a}}$ & $10.46^{\mathrm{a}}$ & \multicolumn{2}{|c|}{$9.16^{\mathrm{ab}}$} & $15.10^{\mathrm{bc}}$ & $2.05^{\mathrm{c}}$ & $2.50^{\mathrm{a}}$ & \multicolumn{3}{|c|}{$13.99^{\mathrm{b}}$} & $0.64^{\mathrm{bc}}$ \\
\hline Inf. & 1.0 & $2092.00^{\mathrm{a}}$ & $91.98^{\mathrm{a}}$ & $10.25^{\mathrm{ab}}$ & \multicolumn{2}{|c|}{$9.53^{\mathrm{ab}}$} & $15.60^{\mathrm{b}}$ & $2.08^{\mathrm{c}}$ & $2.20^{\mathrm{b}}$ & \multicolumn{3}{|c|}{$14.77^{\mathrm{a}}$} & $0.52^{d}$ \\
\hline \multirow[t]{11}{*}{ N. Inf. } & 1.0 & $2090.00^{\mathrm{a}}$ & $92.79^{\mathrm{a}}$ & $9.51^{\mathrm{c}}$ & 9.7 & & $14.31^{\mathrm{d}}$ & $1.18^{\mathrm{d}}$ & $2.51^{\mathrm{a}}$ & & $4.34^{\mathrm{a}}$ & & $0.67^{\mathrm{ab}}$ \\
\hline & SEM & 34.90 & 1.35 & 0.13 & 0.2 & & 0.23 & 0.03 & 0.04 & & .194 & & 0.02 \\
\hline & \multicolumn{13}{|c|}{ Infection status main effect } \\
\hline & Inf. & $1789.61^{\mathrm{b}}$ & $92.99^{\mathrm{b}}$ & $9.96^{\mathrm{a}}$ & $9.61^{\mathrm{a}}$ & \multicolumn{2}{|c|}{$14.81^{\mathrm{b}}$} & $2.25^{\mathrm{a}}$ & $2.23^{\mathrm{b}}$ & \multicolumn{2}{|c|}{14.47} & \multicolumn{2}{|c|}{$0.58^{b}$} \\
\hline & N. & $2020.43^{\mathrm{a}}$ & $93.36^{\mathrm{a}}$ & $9.59^{\mathrm{b}}$ & $9.51^{\mathrm{b}}$ & \multicolumn{2}{|c|}{$16.15^{\mathrm{a}}$} & $1.76^{\mathrm{b}}$ & $2.51^{\mathrm{a}}$ & 14.38 & & $0.67^{\mathrm{a}}$ & \\
\hline & SEM & 20.15 & 0.78 & 0.08 & 0.14 & & & 0.02 & 0.02 & 0.13 & & 0.01 & \\
\hline & Monodora L & vel main eff & & & & & & & & & & & \\
\hline & $0 \%$ & $1588.41^{\mathrm{b}}$ & 90.06 & $9.26^{\mathrm{c}}$ & 9.50 & 16. & & $2.26^{\mathrm{a}}$ & $2.43^{\mathrm{a}}$ & 16.59 & & $0.65^{\mathrm{a}}$ & \\
\hline & $0.5 \%$ & $2035.65^{\mathrm{a}}$ & 92.09 & $10.19^{\mathrm{a}}$ & 9.58 & 14. & & $2.12^{\mathrm{a}}$ & $2.29^{b}$ & 14.90 & & $0.62^{\mathrm{b}}$ & \\
\hline & $1.0 \%$ & $2091.00^{\mathrm{a}}$ & 92.38 & $9.88^{\mathrm{b}}$ & 9.62 & 14. & & $1.63^{\mathrm{b}}$ & $2.38^{\mathrm{a}}$ & 14.96 & & $0.60^{\mathrm{b}}$ & \\
\hline & SEM & & 0.95 & 0.09 & 0.17 & 0.1 & & 0.02 & 0.02 & 0.16 & & 0.01 & \\
\hline
\end{tabular}




\section{Onunkwo and Ukoha}

poultry feed additive which can compete favorably with the harmful chemicals or synthetic additives that are not consumer friendly.

Table 3 summarizes the effects of Aspergillus flavus infection and Monodora myristica spice on the carcass characteristics of broilers fed aflatoxininfected and non-infected diets. The Monodora-free diet recorded $9.26 \%$ drumstick, $2.26 \%$ liver $0.65 \%$ kidney and $2.43 \%$ gizzard, whilethe diet that had $0.5 \%$ Monodora myristica yielded $2.12 \%$ liver and $2.29 \%$ gizzard. Inclusion of Monodora up to $1.0 \%$ recorded $1.63 \%$ liver weight. Aspergillus flavus alone caused a reduction in live weight, dressed weight, thigh, kidney, breast meat, gizzard and an enlargement in the liver. Monodora myristica inclusion level also affected $(p<0.05)$ all the parameters except dressed weight, thigh and back cut. Kidney and liver were observed to decrease as the level of inclusion of Monodora myristica increased. The interaction of Monodora myristica and Aspergillus flavus on the parameters were significant $(\mathrm{p}<0.05)$.

The live weight, dressed weight, thigh and liver weights were enhanced by the inclusion of Monodora myristica. Dressed weight and thigh weights were improved as the level of inclusion of Monodora myristica increased. Also the liver weight decreased as the level of inclusion of the spice increased suggesting that it could help to reduce stress on the liver. Largest liver weight was observed in the infected diet that lacked Monodora. Inclusion of $0.5 \%$ and $1.0 \%$ Monodora myristica in the diet caused a reduction $(p<0.05)$ in the liver weight. For the non-infected diets, $1.0 \% \mathrm{M}$. myristica inclusion level resulted in the lowest $(\mathrm{p}<0.05)$ liver weight. However, 0.5\% Monodora did not make any significant impact over the control on liver weight.
Liver weight was significantly $(\mathrm{p}<0.05)$ enlarged by Aspergillus flavus in the absence of Monodora myristica. The highest $(p<0.5)$ weight of the kidney was observed in the group fed non-infected control diet. In the presence of Aspergillus flavus infection, Kidney weight decreased $(\mathrm{p}<0.05)$ when Monodora was included at $1.0 \%$ the liver is the principal target of aflatoxin metabolite. The increase observed in liver size observed in the infected diet without Monodora could be due to increased pressure from detoxification of the Aspergillus flavus infection. The size of the kidney recorded in the infected Monodora-free diet could be due to the increased metabolic rate of the organ in an attempt to reduce the toxicity in the system arising from the presence of aflatoxin in the Aspergillus flavus.

\section{References}

Alharti, M. A. 1997. Efficiency of the utilization of some spices and herbs with or without antibiotic supplementation on the growth performance and carcass characteristics of broiler chicks Fac. Of Metero, Environ and Arid Land Agri., King Abdulaziz Univ., Jedda, Saudi Arabia.

A.O.A.C. 1990. Association of official Analytical Chemists. Official methods of Analysis. $15^{\text {th }} \mathrm{edn}$. Washington D.C.

Barakat, M. Z., Shehab, S. K., Darwish, N. and Zahermy, E. I. 1973. Determination of ascorbic acid from plants. Analyst biochemistry 33: 8993.

Fente, C. A., Jaimez, B. I., Franco, C. M. and Cepede, A. 2001. A new additive for culture media for rapid determination of aflatoxin producing Aspergillus strains. 
Effect of African nutmeg (Monodora myristica)spicein aflatoxin-infected diets on growth performance of broilers

Applied Environmental Microbiology 67: 4858-4862.

Gerbert, S., Stanbel, M., Messikommer, R. and Wenk, C. 1999. Rhubarb als. Alternative zuantimikrobiellen Leistungs-forderm (AML) imFerkel- und broilerfutter. In: gesunde Nutziere (Ed, Sutter, M. Kreuzer and C.Wenk). p 165- 166.

Holdas, A. and May, K. N. 1966. Fish oil fish flavor of Eggs carcasses of hens. Poultry Sci. 45: 1405 -1408.

Johnson, C. M. and Ulrich, A. 1959. Analytical Methods for use in plants analysis. Bill 766 California. Agric Exp. Staberkeley. Schum Pierre EX Beille. Global J. Pure and Applied Sci. 6: 83-870

Kozakiewic, Z. Z. and Smith, O. 1994. Biotechnology Handbook. 7: 23- 40.

McDonald, P., Edwards, R. A., Greenhalgh, J. F. D. and Morgan, C. A. 1995. Aflatoxin in groundnut meal-poison to Turkey poults and ducklings. In Animal Nutrition. $5^{\text {th }}$ Edition (Pearson Education Limited, Essex CM 20 2JE, United kingdom. P 522-523

Okwu, D. E. 2004. Phytochemical and vitamin content of indigenous Spices of South Eastern Nig. J. Sustain. Agric. Environ 6(1):30-37.
Samarasinghe, K. and Wenk, C. 2002. Tumeric (cucurma longa) and mannan oligosaccharide as antibiotic replacers in broiler diets. I n : O p t i m a le $\mathrm{N} u$ utzungnderfutterressourcenin zusammenspielvonberg-und $\mathrm{T}$ a 1 g e b e $\mathrm{i}$. EinBeitragzuminternationlenjahr $\mathrm{d}$ e $\mathrm{r} \quad \mathrm{B}$ e $\mathrm{r} \mathrm{g}$. Schriftenreiheausdminstitu fur $\mathrm{NutztierWissenschafen.}$ (Ed.M.Kreuzer, Wenk. C. and Lanzinu, T) 23: 124-125.

Sonia, K. B., Lahirib, P., Chackradeob, P., Bhideb, S. V. and Kuttan, R. 1997. Protective Effect of food Additives on Aflatoxin-induced $\mathrm{m} \mathrm{u} t$ a g e $\mathrm{n}$ i c i t y a n d hepatocarcinogenicity. Amala cancer Research center, Amala Naga, Trichur, Kerala, India.

Ukoha, O. A. 2011. Effect of African Nutmeg (Monodora myristica) Spice as a feed additive on the growth performance of broiler chickens. Ph.D Dissertation. Department of Animal Nutrition and Forage Science, Michael Okpara University of Agriculture, Umudike.

Received: $13^{\text {th }}$ October, 2016 Accepted: $16^{\text {th }}$ March, 2017 